University of Wollongong

Research Online

Faculty of Social Sciences - Papers (Archive) Faculty of Arts, Social Sciences \& Humanities

$1-1-2018$

Rabies response, One Health and more-than-human considerations in Indigenous communities in northern Australia

Christopher J. Degeling

University of Wollongong, degeling@uow.edu.au

Victoria Brookes

University of Sydney

Tess Lea

University of Sydney

Michael P. Ward

University of Sydney

Follow this and additional works at: https://ro.uow.edu.au/sspapers

Part of the Education Commons, and the Social and Behavioral Sciences Commons

Research Online is the open access institutional repository for the University of Wollongong. For further information contact the UOW Library: research-pubs@uow.edu.au 


\title{
Rabies response, One Health and more-than-human considerations in Indigenous communities in northern Australia
}

\begin{abstract}
Australia is currently canine rabies free; however, the spread of rabies in eastern Indonesia poses an increasing risk to northern Australia. Domestic dogs are numerous in East Arnhem Land (EAL) and the Northern Peninsular Area (NPA), usually unrestrained and living in close relationships with humans. The response to any rabies outbreak on Australian territory will focus on dog vaccination, controlling dog movements and depopulation. A One Health approach to zoonotic disease control should seek to copromote human and animal health, whilst also seeking to accommodate the preferences of affected communities. We report on 5 collaborative workshops and 28 semi-structured interviews conducted between January 2017 and June 2018 with: (i) EAL and NPA community members; (ii) Indigenous Rangers in EAL and NPA; and (iii) residents of Cairns, the local regional centre. Storyboard methodologies were used to work with participants and explore what rabies response measures they thought were justified or unacceptable, why they held these views, and what other steps they believed needed to be taken. Key findings include that the capacity of the NPA and EAL communities to contribute/adapt to a biosecurity response is limited by structural disadvantage including poor infrastructure (such as lockable premises and intact fences) and appropriate information, dominant cultural norms and food security concerns. Dogs and dingoes can have great cultural and social importance; key interventions might be accommodated within cultural beliefs and long-standing norms of dog management if sufficient effort is made to adapt interventions to local contexts and community preferences. Adopting such a 'strengthsbased' approach mandates that the communities at greatest risk need help to prepare for and develop strategies to manage a biosecurity response to a rabies incursion. This would include listening to individual and community concerns and attending to the educational and infrastructural needs for supporting different groups to respond appropriately.
\end{abstract}

\section{Keywords}

health, more-than-human, considerations, one, indigenous, rabies, communities, northern, response, australia

\section{Disciplines}

Education | Social and Behavioral Sciences

\section{Publication Details}

Degeling, C., Brookes, V., Lea, T. \& Ward, M. (2018). Rabies response, One Health and more-than-human considerations in Indigenous communities in northern Australia. Social Science and Medicine, 212 60-67. 
Title: Rabies response, One Health and more-than-human considerations in Indigenous communities in Northern Australia

Ref: SSM-D-18-01014R1

Authors: Chris Degeling ${ }^{1 *}$, Victoria Brookes ${ }^{2}$, Tess Lea ${ }^{3}$, and Michael Ward ${ }^{2}$

${ }^{1}$ Research for Social Change, Faculty of Social Science, The University of Wollongong, Australia

${ }^{2}$ Sydney School of Veterinary Science, The University of Sydney, Australia

${ }^{3}$ Department of Gender and Cultural Studies, Faculty of Arts and Social Sciences, The University of Sydney, Australia

*Corresponding author:

Dr Chris Degeling

E: degeling@uow.edu.au

A: Research for Social Change, Faculty of Social Science, Building 233, G05D, Innovation

Campus, The University of Wollongong, NSW, 2500

Acknowledgements:

Funding for this research was provided by the National Medical Research Council of Australia (\#1083079) and the Commonwealth Department of Agriculture and Water Resources. The funding organizations had no role in study design, the collection or analysis of the data, data interpretation, writing, or the decision to submit for publication. We thank the three anonymous reviewers for their engagement and insights. We are indebted to the peoples of East Arnhem Land, Northern Peninsular Area and Cairns for sharing their insights with us and for helping us to understand. 
Title: Rabies response, One Health and more-than-human considerations in Indigenous communities in Northern Australia

\section{Abstract}

Australia is currently canine rabies free; however, the spread of rabies in eastern Indonesia poses an increasing risk to northern Australia. Domestic dogs are numerous in East Arnhem Land (EAL) and the Northern Peninsular Area (NPA), usually unrestrained and living in close relationships with humans. The response to any rabies outbreak on Australian territory will focus on dog vaccination, controlling dog movements and depopulation. A One Health approach to zoonotic disease control should seek to co-promote human and animal health, whilst also seeking to accommodate the preferences of affected communities. We report on 5 collaborative workshops and 28 semi-structured interviews conducted between January 2017 and June 2018 with: (i) EAL and NPA community members; (ii) Indigenous Rangers in EAL and NPA; and (iii) residents of Cairns, the local regional centre. Storyboard methodologies were used to work with participants and explore what rabies response measures they thought were justified or unacceptable, why they held these views, and what other steps they believed needed to be taken. Key findings include that the capacity of the NPA and EAL communities to contribute/adapt to a biosecurity response is limited by structural disadvantage including poor infrastructure (such as lockable premises and intact fences) and appropriate information, dominant cultural norms and food security concerns. Dogs and dingoes can have great cultural and social importance; key interventions might be accommodated within cultural beliefs and long-standing norms of dog management if sufficient effort is made to adapt interventions to local contexts and community preferences. Adopting such a 'strengths-based' approach mandates that the communities at greatest risk need help to prepare for and develop strategies to manage a biosecurity response to a rabies incursion. This would include listening to individual and community concerns and 
attending to the educational and infrastructural needs for supporting different groups to respond appropriately.

\section{Keywords:}

Australia; rabies control; health policy; Indigenous health; biosecurity; housing; story-boarding methodologies 


\section{Introduction}

Canine rabies is a fatal, viral zoonosis most commonly transmitted via the bite of an infected dog. The global burden of rabies is high: there are estimated to be more than 50,000 human fatalities each year, mainly in Asia and Africa (Hampson et al., 2015). Australia is currently free of canine rabies, but a zoonotic incursion is a realistic and imminent threat. Rabies is endemic in most of the western Indonesian islands. It has spread eastward along the archipelago - probably through human activities such as taking sub-clinically infected dogs on fishing trips and journeys to visit relatives (Tenzin \& Ward, 2012). There are vibrant sea trade routes between northern Australia and rabies-affected areas and the cultural links between these communities are strong. The movement of dogs across national borders is restricted by international regulations, but most experts believe it is only a matter of time before a rabies-infected dog enters the northern Australian mainland from Indonesia direct or via the coastal regions of Papua New Guinea (Hudson et al., 2017; Sparkes et al., 2015). In the absence of an effective and rapid response, rabies could conceivably become endemic to large parts of northern Australia (JohnstoneRobertson et al., 2017).

\section{FIGURE 1 HERE}

Risk assessment models indicate that the Cape York Northern Peninsula Area (NPA) in Queensland and coastal areas of East Arnhem Land (EAL) in the Northern Territory (Figure 1.) are the most likely locations for a rabies incursion on the Australian mainland (Dürr \& Ward, 2015). Dogs are numerous and free-roaming in Aboriginal and Torres Strait Islander (Indigenous) communities in both of these areas (Burleigh et al., 2015). Likewise, people can also be widely distributed. Many live in larger regional centres, while some live in what are called outstations or homelands, comprising smaller settlements where Indigenous people might permanently or periodically reside, to be close as possible to the sites for which they hold primary custodial responsibility. As well as being used for hunting and as physical and spiritual 
protectors, many dogs live in close relationship with community members. Dogs can have immense importance to different Indigenous people, because they are totems or are central to Dreaming stories (Constable et al., 2010; Rose, 2011). Like most Australian canines, these dogs are not vaccinated against rabies because the disease is currently exotic to the continent. Unlike other regions of the world where rabies is endemic, domestic dogs in regional and remote northern Australia also live in contact - and are sometimes contiguous - with feral dog and wild dingo populations (Dwyer \& Minnegal, 2016). A rabies outbreak in either the domestic, feral or wild dog populations in northern Australia could have devastating, long-term impacts on both human and animal health. Therefore, a timely and effective response to a rabies incursion is important to increase the probability of control and prevent human deaths. However, controlling the risks in affected areas would require a re-orientation of how individuals and communities live with and among domestic and wild dog populations. Interventions that involve dogs in Indigenous communities can be contentious and highly politicized. In the past, the approach taken by authorities to perceived public health and social problems associated with dog overpopulation has involved the arbitrary culling of dogs found in the community, most often without consent (Musharbash, 2017; Rose, 2011). This history has eroded trust, such that there might be suspicion and a lack of broad support for public health measures in the event of a rabies outbreak.

\section{Policy Background: AUSVETPLAN}

Australian biosecurity agencies have a range of disease preparedness plans, including one to address a rabies incursion (Animal Health Australia, 2011). The AUSVETPLAN for rabies outlines the key control measures and coordination requirements to ensure the rapid containment and eradication of the disease from Australian territory. The most likely scenario is that a fishing boat or yacht will bring a dog with a sub-clinical rabies infection illegally through the northern quarantine zone. If this dog then escaped into the bush or was purchased or given 
to someone as a gift, then the large number of free-roaming dogs in and around the local communities and outstations provide a suitable host population for rabies transmission. Because rabies can have a long incubation period, it is possible that the disease would spread undetected through the dog population for many months and the first indication of an incursion might be a human case (Dürr \& Ward, 2015; Sparkes et al., 2016b). Because rabies is a category 1 notifiable disease, when an incursion is detected, disease control measures would be implemented within a 'declared area' in accordance with the Biosecurity Act (2012) and relevant legislation.

\section{Textbox 1 HERE}

Experiences of controlling rabies in other countries indicates that the response would be undertaken in stages (Textbox 1), consistent with the current epidemiological characteristics of the outbreak (Putra et al., 2013; Tenzin \& Ward, 2012). The key objectives of stages 1 and 2 are to stop dog movements and provide blanket vaccine coverage. Initial measures would be implemented rapidly, ideally within a few days of confirmation of the index case. To prevent susceptible animals (including dogs, cats, horses, cattle, sheep, and pigs) being moved to other areas, a restricted area (RA) would be imposed around the outbreak. Once the vaccination campaign had commenced a larger control area (CA) would be established to create a buffer zone between infected and uninfected areas. AUSTVETPLAN does contain provisions for limited and cautious use of culling, but this is generally not seen as being a useful measure for rabies control in Australia. Culling wild dogs causes increased levels of movement and fighting within the population, while targeting domestic dogs will cause some owners to hide or move sub-clinically infected dogs (Morters et al., 2013; Windiyaningsih et al., 2004). Both outcomes will almost certainly worsen the outbreak (Dürr \& Ward, 2015; Sparkes et al., 2016b). In the final stage of the response (Stage 3), dingoes and wild dogs in and around the control area would be monitored for signs of rabies. Surveys of hunters indicate that interactions between hunting 
dogs and wild dogs could exacerbate a rabies outbreak (Sparkes et al., 2016a). If the disease escaped the RA and/or became established in wild animal populations then the eradication campaign would be protracted (months to years), requiring communities living within the CA to regularly vaccinate all their dogs and adhere to dog movement restrictions until the area is again declared disease free.

Clearly, the public health response to a rabies incursion in northern Australia is likely to have substantial impacts on the local Indigenous and Torres Strait islander communities. As well as the risk of rabies transmission, most of the interventions mandated by AUSVETPLAN are restrictive, potentially burdensome, and are therefore, contentious. Even though AUSVETPLAN explicitly acknowledges that enlisting broad local support will be essential to successful implementation, the willingness and capacity of individuals and communities living in the areas at greatest risk of a rabies outbreak to adapt to and tolerate such a response is unknown. Previous studies of the relationships between Indigenous communities and dogs emphasize the need to find culturally appropriate solutions to issues of dog management (Constable et al., 2010). To develop a better understanding of the practical, cultural and ethical issues a rabies outbreak in northern Australia would likely entail, we sought the perspectives of community members on how the interests of individuals, communities, and animals should be accommodated in response planning and implementation. In particular we were interested in which measures they thought were justified in the circumstances, those that were unacceptable, why they held these views, and what other steps they believed needed to be taken. Our study was approved by the Human Research Ethics Committee at the University of Sydney.

\section{Methods}

\section{Overview}

The core of this study is a series of interviews and collaborative workshops held in EAL, the 
NPA, and Cairns to explore the following questions:

1. What should and should not be done to prevent and control canine rabies in northern Australia?

2. What are the roles and responsibilities of government officers and members of the community in the event of a canine rabies outbreak?

The EAL and NPA communities were chosen as research sites because they have been identified as being at higher risk of a rabies incursion. The city of Cairns (more than 1000 kilometres to the south) was included in the study because it is closely interlinked with travel, trade and employment in both the NPA and EAL, and therefore, would probably be one of the first large urban areas affected by rabies if efforts to control the outbreak failed. The collaborative workshops were conducted in English. For the interviews, researchers were accompanied by community members who acted as translators when participants preferred to talk in languages other than English. Interviews were conducted between January 2017 and June 2018; the workshops took place between May 2018 and June 2018. All interview and workshop participants were aged 18 or older.

\section{$\underline{\text { Data collection }}$}

\section{Interviews}

Informal semi-structured interviews were conducted with 28 community members from the EAL and the NPA (Figure 1); 23 in the months before the workshops and two in the NPA and three in the EAL immediately afterwards (Supplementary Table 1). Recruitment focused on capturing the diversity of perspectives present in each community rather than attempting to represent a unified community view. Most participants were Aboriginal or Torres Strait Islander people who varied in age and occupation. They spoke as local residents and from their experiences performing specific roles such as: traditional elders and councillors, teachers, human 
health professionals, veterinarians, and animal control workers. Interview participants were asked open-ended questions and encouraged to talk freely about topics they considered to be important so as to capture their knowledge, views and preferences. Questions focused on participant perspectives on dog health, the purpose and importance of dogs and dingoes to the community, likely barriers and enablers to establishing a rabies surveillance program, and their opinions about the acceptability and perceived legitimacy of measures contained in AUSVETPLAN should there be a rabies outbreak (examples of the questions asked in the interviews are included in Supplementary materials). Except for the biosecurity officers and human health professionals we interviewed in the NPA and EAL, all of the participants had limited knowledge of rabies. We did not conduct interviews with residents of Cairns. Relevant by-laws, organizational and grey literatures were consulted to prepare for and to provide context to our observations and interview responses. For the current paper, we focused on interview data and policy documents relevant to responses to a rabies incursion in northern Australia. Reporting and analysis of the data pertaining to establishing a rabies surveillance program in the EAL and NPA is reported elsewhere (Brookes et al., 2017). Interview participants were offered parasiticides for their dogs, in appreciation of their time and inputs.

\section{Collaborative Storyboard Workshops}

We conducted two collaborative co-compositional workshops in EAL $(n=22)$, two in the NPA $(n=26)$, and one in Cairns ( $n=13)$. Participants from NPA and EAL communities were recruited from two groups: people working as Indigenous rangers, and members of the general public (Supplementary Table 2). To ensure that participants were not intimidated and expert voices did not dominate group discussions, human health professionals, biosecurity officers and veterinarians were excluded from taking part in any of the workshops. Members of the public were invited to attend because of their knowledge and experience of dogs and dog-related activities in their local community. We chose to work with Indigenous rangers in the NPA and 
EAL because they are usually drawn from the communities they serve, and the role requires them to act as custodians of the local 'Indigenous estate' (Altman \& Kerins, 2012; Robinson \& Wallington, 2012). Workshop participants in Cairns were recruited from the general public by a professional research service using random digit dialling. Unlike the EAL and NPA groups, the composition of participants in the Cairns group was predominantly non-Indigenous.

A preliminary workshop was held with community members in Yirrkala (EAL) in which participants were asked to discuss and provide their perspectives on rabies surveillance and the likely responses and interventions that would follow an outbreak. The data collected on local preferences for community-based rabies surveillance systems was clear. However, discussions among and comments from participants highlighted the importance of contextual detail in shaping their judgements and opinions on the feasibility and acceptability of different rabies response measures. Based on the outcomes and feedback from this event we introduced storyboarding methodologies to subsequent workshops in the EAL, NPA and Cairns to facilitate the discussions with and among participants. Storyboarding encourages a different kind of research participation in that it enables lay-people to develop and communicate their knowledge about a specific issue using stories and non-textual media (Laycock et al., 2011; Smith, 2013). These methods have been used in Indigenous research to centralize 'story' as a key medium for sharing existing data and allow interpretation or meaning-making to be directed by participants, increasing the likelihood that the results reflect their understandings (Kovach, 2010). Storyboarding has been used in public health research to help Indigenous communities in South Australia set priorities to improve youth diet and activity levels (Street et al., 2018); design interventions to discourage tobacco use during pregnancy by Indigenous women in regional NSW (Gould et al., 2013); and to explore women's experiences of male circumcision in Papua New Guinea in the context of the local Human Immunodeficiency Virus epidemic (RedmanMacLaren et al., 2014). In the current study, storyboarding stimulated detailed discussions and 
representations of people's knowledge of how dogs and dingoes are valued and cared for within their communities, and their expectations as to the likely impacts of a rabies outbreak and the subsequent implementation of AUSVETPLAN in these settings.

A non-Indigenous researcher moderated the collaborative workshops. Plastic tokens and animal figurines were used to represent specific fictional people and animals; a felt storyboard with squares of differently patterned and coloured fabric was used to depict key sites within the local area. These visual prompts were mobilized across the felt backdrops to dramatize a story about a fictional rabies outbreak which conveyed the following information:

1. the clinical and epidemiological features of rabies infections in dogs and people

2. how a dog with rabies could enter the local area and how the disease would silently spread to other dogs and humans

3. the range and nature of the measures that authorities would put in place in the local area and wider region in an attempt to control the outbreak (Textbox 1).

Drawing on our interview data and previous epidemiological and socio-cultural research, the outbreak narrative presented to each group was first locally contextualized and then actively cocreated by participants so that their discussions, reflections and responses to the clinical, epidemiological and policy information contained in each story was grounded in their contextual knowledge and day-to-day experience of life in the NPA, EAL or Cairns communities. The 5 workshops lasted between 2 and 4 hours. Facilitation focused on creating a safe and respectful space where participants felt comfortable to ask questions and share their insights. Our impression was that opportunities to speak were shared relatively equally across each workshop group - with each participant speaking at least once, and most several times at length during group discussions. To acknowledge their contribution to the study, participants were provided with refreshments and offered a modest honorarium. 


\section{$\underline{\text { Data Analysis }}$}

The project required repeated visits to the NPA, EAL and Cairns to conduct fieldwork, and for the purposes of community engagement and event organization. Consequently our analysis proceeded in tandem with data collection as team members compared and contrasted insights from immersion in the research setting with reflections on the emerging dataset (Borkan, 1999). To facilitate this process, team members made detailed field and reflective notes. Discussions during the interviews and workshops were audio-recorded with participant permission and transcribed in a naturalistic style. A case study approach was taken such that the locality was the unit of analysis (Yin, 2002). The transcripts of all interviews and workshop sessions were qualitatively analysed by the first two authors to identify compare and contrast the key concerns of participants from each setting about the rabies outbreak story presented to them, and the possible options for intervention that they considered. Open coding was used by first two authors to identify the range of arguments, reasons and actions proposed by individuals or discussed by each workshop group. The emergent codes, representative quotes and exchanges from the workshops and interviews were then collated and entered onto an Excel ${ }^{\mathrm{TM}}$ spreadsheet by the lead author to aid analysis.

Consistent with the tenets of Framework Analysis, the first two authors then used a tabular matrix to systematically map how different arguments and reasons appeared across the three research settings (Gale et al., 2013). The results of these processes were refined through comparisons with our fieldnotes (Emerson et al., 1995), relevant peer-reviewed literature and government documents (Krippendorff, 2004). The findings were reviewed and alternative hypotheses and explanations were tested and discussed by all authors at face-to-face meetings and through several iterations of drafting and re-drafting this paper to reach consensus on interpretation. 


\section{Findings/Results}

The presence of domestic dogs is a prominent feature of day-to-day life across the three study sites but there are key differences in the practiced norms of dog-ownership and the regulatory environment in each setting. Our examination of the grey literature found - and subsequent interviews and email interactions with council representatives confirmed - that both Cairns and the NPA have by-laws that pertain to how dog owners should look after their dog. In Cairns people are only allowed to have $1 \mathrm{dog}$ per household unless their property is larger than $450 \mathrm{~m}^{2}$. Like most other urban jurisdictions in Australia, owners in Cairns have to register their dogs with the local council, and keep them on private property or on a leash unless they are in a designated off-leash area. The council in the NPA also requires all dogs to be registered, contained on private property, and what is locally known as the "2-dog rule" restricts each household to owning two dogs (exceptions can be made for hunting dogs). However, while compliance is the norm in Cairns, the by-laws in the NPA are rarely, if ever, enforced except for isolated instances involving dangerous dogs. In contrast, at the time of writing, the regional council for EAL does not have animal by-laws in place but does fund an animal management program that twice a year provides free preventive veterinary services (vaccination, worming, de-sexing) to each community.

\section{$\underline{\text { Relationships between People and Dogs }}$}

Dogs in day-to-day life and dog ownership

Most dogs in the NPA and EAL are free-roaming, and participants described this is an accepted norm of dog-ownership in these communities (Supplementary Table 3). Some dogs wander off and are "adopted" by someone else in the community (without any change of "ownership"), or they are not seen again and are considered to be feral or have died. The expectation in the NPA and EAL is that 'owned' dogs should be free to conduct their own social lives. A workshop participant in the NPA provided this description: 
I have only one dog and she wanders ... that's kind of normal for us ... they know your families' places - so even though you're not at home they just go and see if other family members are at their home and hang out over there.

In contrast, for participants from Cairns, unattended and off-lead dogs were encountered relatively infrequently and generally seen as problematic. Rather than dogs being at large and having independence and agency in how they lived, the underlying assumption was that dogs are the property of their owners, and that all the social and legal obligations entailed by this status to protect and control them should be applied. In some cases this was used as a moral marker that distinguished responsible from irresponsible residents and areas.

\section{The cultural importance of dogs and dingoes}

There are other key contrasts in how different canids are classified and valued within and between the study settings. Participants in EAL emphasized that domestic dogs have great cultural significance for Yolngu (the Aboriginal people of Arnhem Land). Some dogs are given skin-names and play an important social role in the kinship structure as family relatives to people. Dogs are also culturally important in the NPA. Some community members have them as one of their totems (which means they are part of their clan and need to be looked after for future generations). But individual animals are not given the status of a skin name, and thereby, a specific position in the kinship system. Definitions of dingoes and their relationship to dogs also varied. In EAL the categories of camp dogs, feral dogs, wild dogs, and dingoes are not so easily defined because they depend less on the animal's phenotype (and assumed genotype) and more on the context where the dog is encountered and its relationship with members of the community. In contrast, participants from the NPA told us that only animals that look and behave like pure-breeds are dingoes, and, therefore, only these are worthy of special protections; whereas canids that look like cross-bred or hybrids and behave like a domestic dog are a type of 
feral dog. When asked about the distinction between domestic dogs and dingoes, the group in Cairns held a similar view to the people we spoke to in NPA such that the genotype, assumed genotype and comportment of a dingo-type canid determined whether it was native fauna or a pest. Consistent with the norm in Western societies, the attitude of participants in Cairns was that a domestic dog's value depended on it being the subject of claims of ownership and it fulfilling a role as a companion, family pet, or assistance animal, for example.

\section{Dogs and bunting}

In the NPA, in particular, dogs are highly prized for their prowess in pig-hunting. It is not uncommon for people to travel to Cairns to obtain a dog with good 'bloodlines'. We were repeatedly told that hunting dogs are a community resource that facilitate access to more affordable sources of meat, particularly wild pigs. During an interview, a community leader in the NPA noted:

Although two dogs is the regulation ... this can't be stopped. Hunting is big here... they need more dogs.

The high price of food in the NPA and the elevated status of hunting dogs means that hunting dogs are often given special treatment such as medical care (unlike other dogs). When at home they are generally more restricted in where they are allowed to roam, but are free to associate with other dogs in the community. There are also large number of dogs in Cairns used for pighunting - but unlike the NPA these dogs generally are not taken out to public spaces. Both the pig-hunting dogs and their owners were seen by participants in Cairns as being a distinct group who had little to do with other dogs and owners. Participants in the EAL described how hunting-dogs were previously important to community life because they helped to find goanna, but hunting for these animals was now a waste of time because the cane toad invasion had almost wiped out this local food resource. The views of non-Indigenous hunters in Cairns was 
not able to be explored in this project but warrant separate investigation.

\section{Dogs as a social problem / public nuisance}

Study participants in the NPA and EAL described how large groups of dogs occasionally are a public nuisance because of dog fights and excessive barking. 'Humbugging' (that is, begging or stealing) for food was especially problematic for participants in the NPA and some (but not all) communities in EAL, who noted that most of these dogs do not have enough food. Rather than being a form of neglect, it is a common perception that it is the dog's responsibility to find its own food, and not the owners. Because fencing around the local schools and people's houses is often in poor condition, hungry dogs enter people's yards and bother school children at lunch times looking for scraps. An animal health worker in the EAL explained that people just accepted this state of affairs because:

... these dogs don't understand confinement ... And it's not really acknowledged or understood concept ... why would you keep your dogs from wandering?

For participants in the NPA and Cairns, normal canine behaviours such as digging and looking for food were seen as being particularly problematic, especially if the animal was owned by someone else, whereas for participants in the EAL these canine pastimes were simply seen as being what dogs do. While quite a few of the people we spoke to in the NPA and EAL would prefer the norms of dog care to include providing adequate food and secure housing, the lack of suitable fencing and excessive price of $\mathrm{dog}$ food in these communities made that impossible, especially in light of other competing priorities. In contrast, the group from Cairns more clearly directed blame for dogs being 'at large' at their owners. Most dog-owners were considered to behave responsibly and secured their animals at home. A small minority of owners were described as having a more 'laissez faire' attitude to their dogs. As some participants observed, 
these owners were more likely to live in areas of lower socio-economic status, where rental properties and social housing usually have poor quality fencing.

\section{Responses to Control Measures in AUSVETPLAN}

Participants in all three study settings thought that all of the measures contained in stage 1 of the response were justified (Textbox 1). Their underlying rationale was that rabies is potentially fatal for humans, and human life must always be prioritized. All three groups emphasized the need for prior public education so that people are prepared and know what to expect and what to do in the event of an outbreak (Supplementary Table 4). However, while the group in Cairns expected that a rabies incursion would be managed appropriately in their area, those from the other two research sites thought that controlling an outbreak would be difficult in their communities.

Stage 1 - canine census, case identification, contact tracing and quarantine

Most participants living in the NPA and EAL were of the view that completing an accurate census of dog populations and contact tracing would be a challenge, but that the seizure of infected and exposed dogs would be tolerated by most people in their communities. Several people from the NPA and EAL also stressed that some form of prior consultation and permission seeking from owners and elders was required before anything irrevocable was done to these animals, and that if a dog was to be seized, quarantined or destroyed it must still be treated with respect throughout this process. On this, a resident in the NPA noted:

If you approach them [owners] and talk about the problem then they might understand ... listen to what they say ... that dogs are part of clans does not mean you cannot negotiate ... if worse comes to worse we would just have to get rid of our dogs and cry it away. 
In contrast, the group in Cairns thought that if an outbreak was in progress, avoiding delay was more important than organizing a culturally appropriate and graded response. Providing a synopsis at the end of the group's discussion, one workshop participant told us:

If [rabies] comes in here and we've got a small window to deal with this.

You deal with it in a very hard way ... And then, so you seek forgiveness ... not permission.

Participants in Cairns were especially keen to underscore the importance of activating existing municipal systems and infrastructures with strict enforcement such that there was zero tolerance of dog owners doing the wrong thing. Some recognized that many dog owners (especially those living in apartments) would face challenges in managing their animals while control orders were in place. Also, it was recognized that members of their community from disadvantaged areas would need extra support to know what they needed to do to protect themselves, their dogs and the community, especially in the initial stages of the outbreak response. But the view was that it was the responsibility of owners to suggest feasible and acceptable solutions.

Stage 2 and 3 - vaccination, depopulation, long-term controls on dog movements, and monitoring

Mass vaccination of dog populations against rabies was not seen as being in anyway problematic in any of the research settings. However, participants from the NPA and EAL thought that the imposition of strict restrictions on the movement of dogs would be burdensome, if not impossible, because of the number of dogs that people own, how these dogs have learned to behave, and the lack of suitable fencing to contain them at their owner's property (Supplementary Table 4). For participants from EAL, the key concern was the futility of imposing rules in the absence of the necessary infrastructure. During the workshop in Yirrkala, an Indigenous ranger commented:

There would be a real problem with people controlling their dogs because 
... if there was a blanket rule that they have to be inside I don't know how that would be enforced.

In the NPA, people were especially worried about the impacts of a hunting ban on food security (both for people and their dogs). The feeling was that if the RA and surrounding CA were in place for an extended period, people would be forced to ignore movement restrictions in order to hunt and relieve food costs for their families. In contrast, participants in Cairns supported hunting bans with harsh penalties for those who failed to comply. The implications for food security were not part of discussions because pig-hunting is generally seen as a discretionary form of recreation in this community.

When asked what could be done to help owners comply with restrictions of dog movements, in the EAL participant responses were typically framed around collective solutions such as establishing a shared compound for the dogs in the community. Participants in the NPA were more inclined to try and individualize the problem. During one of the workshops in the NPA a senior Indigenous ranger noted:

Owners need to manage their own dogs during an outbreak - focus should be helping them manage their own dogs

The limits of making owners with ineffective fencing responsible were also recognized. Solutions that owners could use during an outbreak, such as chaining the dog to the house, were seen as impractical and too disruptive because they would cause distress to the animal, make it bark and lead to aggression. The lack of community capacity to control roaming dogs meant that some participants who owned dogs were highly risk averse. As one woman in the NPA explained:

... if it's my dog, but it has been in contact with an infected dog ... then I am not going to take any chances. I have children in the house ... the most reasonable thing is to put it down. 
Notably, the culling of healthy wild dogs or their populations was not supported by any participants in any of the three settings. Reasons given included the likelihood that culling would exacerbate the outbreak, and because of the cultural importance of dingoes to NPA and EAL peoples. If the outbreak spread to dingo populations then a trap-vaccinate-release program was judged to be the most appropriate response.

\section{Discussion}

This study adds nuance and contextual detail to One Health research on the risks and potential impacts of a rabies incursion in northern Australia. In most developed countries, laws created to control rabies outbreaks have evolved and been repurposed as instruments to minimize public nuisances - such as barking, dog bites and fouling - associated with free-roaming dogs (Aronson, 2010; Pemberton \& Worboys, 2007). As instruments of governance, these animalcontrol and welfare policies increasingly focus on encouraging people to be 'responsible' dogowners (Rock \& Degeling, 2013). At the minimum, responsible owners should feed their dogs, keep them behind fences at home, have them on a leash in public spaces, and provide them with basic preventive veterinary care. Most importantly, dog owners exercise control over their animal to minimize the potential for them to cause inconvenience, nuisance or harm to other members of their community (Rock et al., 2017). Encultured within a different set of norms, participants from the NPA and EAL prioritized a completely different set of responsibilities for dog owners to those in Cairns. Unlike Western conceptions which hinge on claims to property, in these settings the idea of 'ownership' does not necessarily imply control - dogs are not as strictly bound to a dyadic ownership structure but seen as having their own communities, and as being part of the wider human community. Reports from other settings indicate that moves to control dog populations by requiring registration and limiting the number of dogs owned are treated with suspicion and mistrust - as an extension of past colonial injustices and an attempt to regulate Aboriginal life (Musharbash, 2017). Because the successful implementation of 
AUSVETPLAN both rests on and leverages the capacity of individual dog owners to conform with Western norms of dog control, we have serious concerns as to whether the communities in northern Australia most at risk from a rabies outbreak will be able to comply with these expectations.

Previous research indicates that the status and cultural importance of domestic dogs (and dingoes) varies within and between different Indigenous and non-Indigenous peoples, and attitudes towards dogs and dog ownership are not static (Constable et al., 2008; Smith \& Litchfield, 2009). As noted, Indigenous people can have cultural obligations to dog or dingo populations. In most NPA and EAL communities customary law dictates that wrong-doing directed at dogs requires the wrongdoer to make recompense and "pay-back" the owner. Harming dogs can also have significant impacts and cause sickness for humans - especially those responsible for their Dreaming. This does not mean that these animals are considered as deities or equals; nor does it in any way imply that harms to dogs are trivial or inconsequential. It simply means that dogs need to be shown respect, both as sentient beings and as members of the community, such that circumstances, context and the balance of benefits and harms dictate the permissibility of specific actions. Because vaccination was strongly perceived of benefit to both humans and animals, and not irrevocable, all participants accepted the need for a mass vaccination program for dog populations in the event of a rabies outbreak. Restricting canine movements was seen as being more problematic, but we were told most people would do their best to comply if they understood why it was important.

In contrast, other more coercive and irrevocable Western animal control strategies - such as culling - are seen as being completely inappropriate solutions to problems of dog population management (Constable et al., 2010; Hudson et al., 2016). Nevertheless, the individuals and groups we collaborated with told us that people would be prepared for dogs to be euthanized 
humanely if they believed it was necessary, especially if the animal was sick and human lives were at risk. However, asking and receiving permission to take these types of irrevocable measures might take time. To avoid breaking traditional, law elders need to be identified and listened to, so as to find out how different canids are categorised and to negotiate what can and cannot be done. Unless efforts are made to inform and consult with community leaders, attempts to deal with an outbreak through restrictive measures - such as bans on animal movement and depopulation programs - will place significant burdens on the community, and likely encounter a lack of support and resistance. If insufficient time is allocated for individuals to go back and talk to their extended families about the problem and take stock of the potential impacts on kinship systems they are placed at risk of breaking ties and creating conflict within their family network.

Social and cultural differences in human-dog relations and socio-culturally different responses to rabies control requirements have also been observed on the island of Bali, Indonesia, where the virus was first found in dogs in 2008 (Orr, 2016; Widyastuti et al., 2015). The subsequent failure of early control efforts serves to highlight how rabies response plans and biosecurity protocols must incorporate local knowledge and adequately account for local context (Brookes et al., 2018; Morters et al., 2013). While prior consultation is vitally important for reasons of respect and cultural acceptability, our research also makes clear that those charged with preparing for and responding to zoonotic risks and disease outbreaks in northern Australia must also pay attention to how different capacities and layers of inequality can sit inside otherwise seemingly uniform communities. There are cultural distinctions between each of the study settings that are highly relevant to rabies control, but the major impediment to successful response to a rabies outbreak in EAL and the NPA is likely to be social and material disadvantage. Participants from both settings emphasized that many members of their communities will be unable to act as required. Just because the cultural norm in EAL and the NPA is that dogs should be allowed to roam freely does not mean that this is not amenable to change. However, people who live in housing 
with poor or inadequate fencing will struggle to contain their dogs - even if they understand and accept the need to do so. Improving the fencing around the houses in the NPA and EAL would involve substantial costs and planning, making this type of intervention a low priority and difficult to implement in the first few weeks of an outbreak. Other available solutions such as providing owners with chains to stop their dogs wandering around the community will create other problems and risks. Because they are not free-roaming, dogs that are chained or kept in a yard cannot scavenge and need to be fed, which will require owners to find and use more resources for this purpose. This ties in with the larger impacts of restricting dog movements on the food security and wellbeing of affected communities. In the NPA in particular, dogs are essential to pig hunting practices that provide the community with a cheap source of protein that helps sustain people and their animals.

At the same time, many Indigenous people hold the view that they are happier and healthier when they are hunting or taking part in other traditional cultural activities on their traditional lands and place of heritage - known and described as their 'country' (Burgess et al., 2005; Johnston et al., 2007). A protracted ban on hunting and the experience of life-under-siege (as is often perceived during animal disease outbreaks) could also have impacts on people's identity and opportunities for them to sustain their relationship with country which may ultimately affect their wellbeing and contribute to dysfunction in the wider community (Garnett et al., 2009; Mort et al., 2005). Unless support is provided for people and families to maintain themselves and their animals while restrictions are imposed, it is likely that dog owners will be faced with the choice of breaking the control order or disposing of (killing) their animals. Under these conditions, planned responses to a rabies incursion must be locally situated and developed through consultation with those likely to be affected, so as to best accommodate their cultural and infrastructural needs and preferences. Successful dog health and management programs could provide an exemplar and a conduit through which to improve rabies preparedness in areas at 
high risk, as they typically have a foundation of support from community residents (Constable et al., 2008). Against this background response plans developed by Australian government agencies include the potential for vaccination strategies prior to an anticipated rabies incursion. As the long-term risks and impacts of a rabies incursion are becoming better understood, establishing a vaccination program in the Torres Straight to create a protective 'buffer' between local and Indonesian and Papua New Guinean dog populations should be considered.

\section{Conclusion}

Dogs are held in high regard by most Indigenous Australians. But as we, and others have found, this is not unconditional or universal (Senior et al., 2006). Different attitudes and practices were found to exist within and between all studied communities in northern Australia, but in the event of a rabies outbreak, key interventions might be accommodated within cultural beliefs and longstanding norms of dog management if sufficient effort is made to adapt interventions to local contexts and community preferences. For people living in EAL and the NPA, canine rabies is not just a zoonotic risk to human and animal health, but also a threat to food security, cultural life, social cohesion and, more broadly, the wellbeing of the community. However, the challenge of managing rabies risks in these and other Indigenous settings is not just a matter of prior consultation and permission seeking. The reification of cultural differences must also be resisted so as not to obscure, and fail to respond to, the practicalities and everyday realities entailed by trying to manage dogs differently in these communities. Efforts to enact control in the NPA or EAL through making dog-owners individually responsible for rabies management risks recasting them as morally questionable or failed citizens and ignores the structures and circumstances that stratify their capacity to respond. This amplifies the risks of unwanted outcomes during an incursion response. Adopting a 'strengths-based' approach mandates that the people at greatest risk need help to prepare for and develop strategies to manage a biosecurity response to a rabies 
incursion. This would include listening to individual and community concerns and attending to the educational and infrastructural needs to support different groups, so that community members can respond appropriately. 
Legends for Textbox and Figures

Textbox 1: Measures included in the 2011 AUSVETPLAN for canine rabies

\section{Stage 1}

- Communicate with residents in the declared area, encourage them to report dog bites and unusual animal behaviour, and provide them with strategies to minimise rabies risks

- Establish a restricted area (RA) around the outbreak to stop domestic animals being moved out of the area. The RA could be as small as individual premises or as large as the home range of wild or feral animals.

- Conduct a rapid census of all the dogs in the RA

- Seize, quarantine and destroy any dogs displaying signs consistent with a rabies infection

- Trace and quarantine any dogs who have been in contact with these animals

- Promote and perform euthanasia on old and sick dogs voluntarily surrendered by their owners and seek permission to destroy any unowned or stray dogs in the community

Stage 2

- Once the canine vaccines and appropriately trained personnel are available a larger 'control area' (CA) would be declared around the RA (to act as a buffer between it and non-infected areas)

- Stop all dog movements (including free-roaming, hunting, car travel, etc.) in the CA and insist that all owned dogs are kept at home (within a secure fenced area or on a chain)

- All dogs still 'at large' within the CA would be considered stray or unowned and impounded until claimed and / or destroyed

- Using the dog census, teams of trained responders would rapidly vaccinate all dogs in the RA and CA at their owner's home by going door-to-door

Stage 3

- Monitor dingoes and wild dogs in and around the RA for signs of rabies

- If rabies is found in wild animal population then the RA and CA would be enlarged to contain them and provide a buffer zone for non-infected areas

- Oral vaccines would be deployed throughout the RA to try and eliminate the disease by decreasing the number of susceptible hosts.

- A trap-vaccinate-release program might be initiated in the RA or on the boundary between it and the CA if oral vaccination is proving to be ineffective.

- Limited and cautious use of culling of a specific animal population (only as a last resort) after careful consideration of the circumstances

- 3 weeks after the mass vaccination program is completed and if there are no further rabies cases, owners of vaccinated dogs in the CA are likely to be allowed to move their dogs between secure premises after applying for a receiving a permit

- Any dogs moved from the CA to the RA will not be permitted to return to the CA until restrictions are lifted 

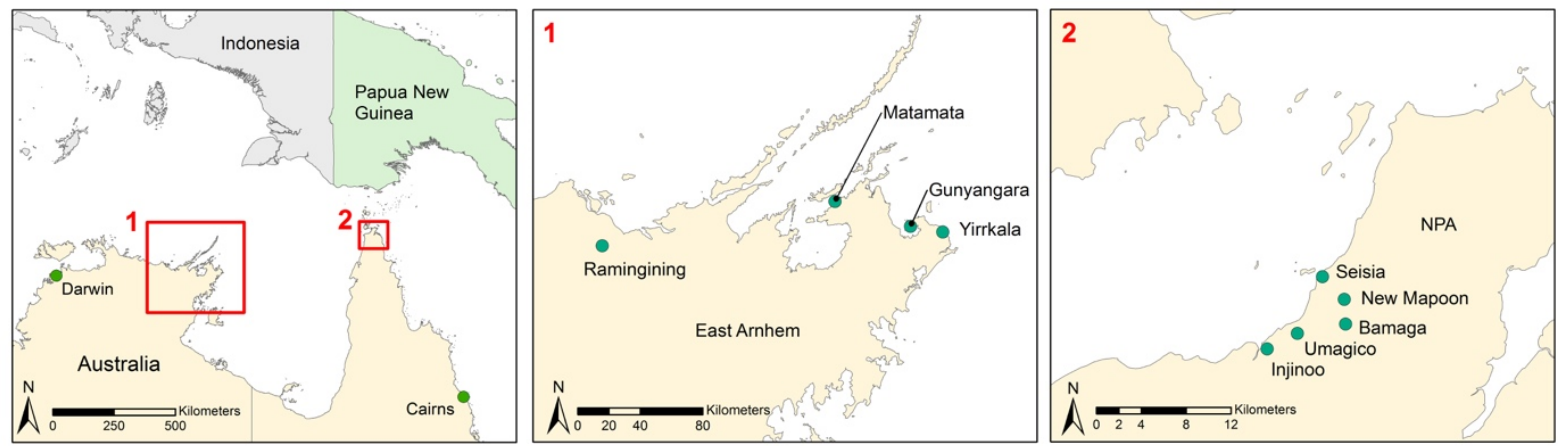

Figure 1: Map of the study region (far left). Inset 1 (centre map) is East Arnhem Land (EAL), and inset 2 (far right map) is the Northern Peninsular Area (NPA)

Supplementary Table 1: Background and location of informal interview participants

\begin{tabular}{|l|c|c|}
\hline & $\begin{array}{c}\text { Northern } \\
\text { Peninsular } \\
\text { Area }\end{array}$ & $\begin{array}{c}\text { East } \\
\text { Arnhem } \\
\text { Land }\end{array}$ \\
\hline Community Elders, Local Leaders and Councillors & 3 & 2 \\
\hline Local Residents & 5 & 5 \\
\hline Council Workers, Biosecurity \& Environmental Health Officers & 4 & 2 \\
\hline Teachers, Human Health Workers and Veterinarians & 4 & 3 \\
\hline Total & 16 & 12 \\
\hline
\end{tabular}

Supplementary Table 2: Characteristics of Collaborative Workshop Participants

\begin{tabular}{|c|c|c|c|c|c|}
\hline & $\begin{array}{c}\text { Northern } \\
\text { Peninsular } \\
\text { Area } \\
\text { Public } \\
(\mathrm{n}=13)\end{array}$ & $\begin{array}{c}\text { Land \& Sea } \\
\text { Rangers }^{\phi} \\
(n=13)\end{array}$ & $\begin{array}{l}\text { Cairns } \\
\text { Public } \\
(n=13)\end{array}$ & $\begin{array}{c}\text { Yirralka } \\
\text { Rangers }^{\#} \\
(\mathrm{n}=12)\end{array}$ & $\begin{array}{c}\text { Yirrkala } \\
\text { Public } \\
(n=10)\end{array}$ \\
\hline \multicolumn{6}{|l|}{ Age (years) } \\
\hline$<35$ & 6 & 8 & 6 & 6 & 6 \\
\hline $35-65$ & 6 & 5 & 6 & 6 & 2 \\
\hline$>65$ & 1 & 0 & 1 & 0 & 2 \\
\hline \multicolumn{6}{|l|}{ Gender } \\
\hline Male & 5 & 11 & 6 & 7 & 8 \\
\hline Female & 8 & 2 & 7 & 5 & 2 \\
\hline \multicolumn{6}{|c|}{$\begin{array}{l}\text { Cultural Background } \\
\#\end{array}$} \\
\hline Indigenous & 9 & 13 & 0 & 6 & 10 \\
\hline Non-Indigenous & 4 & 0 & 13 & 6 & 0 \\
\hline
\end{tabular}


Dogs in household

$\begin{array}{llllll}\text { Yes } & 8 & 10 & 7 & 7 & 6\end{array}$

No

5

3

6

4

Socio-Economic status of suburb*

$\begin{array}{cccccc}\text { Low } & 13 & 13 & 4 & 12 & 10 \\ \text { Middle } & 0 & 0 & 6 & 0 & 0 \\ \text { High } & 0 & 0 & 3 & 0 & 0\end{array}$

$\phi_{\text {The Indigenous Rangers in the Northern Peninsula Area are known as Land \& Sea Rangers }}$ \# The Indigenous Rangers in Yirrkala in East Arnhem land are known as the Yirralka Rangers * Based on Socio-economic Index for Area (SEIFA) 


\section{Examples of questions asked during the semi-structured EAL/NPA interviews}

The question asked and the focus of each interview will depend on the background and experiences of the interviewee.

\section{Topic 1: Community concern for dogs}

- There are lots of different ways of looking after dogs; how do people look after dogs around here?

PROBES: Ask community members to describe common practices and modes of dog care. Explore why there are free-roaming dogs and identify concerns, including dog health. Ask what the current levels are for these concerns.

- We know that some dogs important than others. What is the value of a specific dog to its owner, owner's families and what is the value of the dogs that live around here to the whole community?

PROBES: ask about dog dreaming, dog purpose, demographics of dog owner, cheeky dogs, kinship system...This discussion might include the definition of a 'cheeky dog', the frequency of dog bites within and outside the home. It also might include discussions about dog travel.

- Do people ever report health concerns about their dogs or other dogs?

- Are their circumstances or reasons that people would not report health concerns about their dog?

PROBES: ask about a recent time a dog they know was unwell - and explore the motivation and barriers to report concerns about dogs to other community members or organizations.

- Dogs and dingoes both live around here. Do they cause problems and are they treated the same way?

- Do you ever see dogs and dingoes hanging out together?

PROBES: explore differences and similarities in the value and cultural role of dogs and dingoes and how troublesome dogs are managed in the community

\section{Topic 2: Effective modes of communication within and between communities.}

- If there is an important announcement for the community, how do you make sure that everybody knows about it?

- How do people communicate between communities?

- How do you think we could get people to tell us concerns about their dogs?

PROBES: ask about a recent time that important information or news about a new problem spread through the community - how did this happen and why did lots of people pay attention

Topic 3: Levels of expectations about dog health.

- What diseases do you see in your dogs?

PROBES: Show pictures of dogs with conditions like rabies, snake-bite and toad toxicity and ask participants to describe what happens/clinical signs. Explore their 
understanding of what is wrong with the dog? What is the likely outcome of the sickness? Can vets do much about these sorts of dogs? Is there any point having a vet or Animal Health Worker see the dog?

Topic 4: Awareness of biosecurity regulations and rabies.

- Have you heard of rabies? - and if so where did you find out about it?

PROBES: leave space to let participants tell you about what they know about rabies if they want to but do not ask them directly

- When you travel, are you aware of quarantine zones and biosecurity requirements? (This question specific to NPA residents).

\section{Topic 5: Perceptions of different rabies control measures.}

- Do many people around here vaccinate their dogs?

- Would more people like to vaccinate their dogs? / how did things get the way they are now?

- If there is an outbreak of a nasty disease like rabies in dogs in this area, what do you think would happen if the government asked everyone to keep their dogs locked in their yards or on a chain?

- What would be the consequences if people had to keep their dogs locked up for 5 or 6 weeks?

- Sometimes if there is an outbreak of a nasty disease in animals like rabies that can also kill humans, and vaccination is not working, the government decides that it needs to get rid of a lot of dogs to help control the disease. How do you think people around here would respond to this measure if there was a rabies outbreak?

PROBES: explore attitudes to vaccinating dogs and the participant's perceptions of the social and cultural impacts, feasibility and effectiveness of different types of control measure.

- If there was a rabies outbreak in this area and people were at risk of being bitten - what would be the best way of helping the community manage the situation?

- If there was an outbreak of a rabies in dogs in this area, what should we do about the dingoes who could get the same disease?

PROBES: ask about and discuss what they think could and should be done if there was an outbreak in their area - for both dog and dingo populations

\section{Topic 6: health worker's perspectives of human health and community dogs.}

- Do residents seek treatment for bite wounds at health centers?

- Do you like community dogs and acknowledge them when they come with their owners to the clinic, or you visit patients in their homes?

- What do you think is the most appropriate way to deliver health messages to community members? 


\section{Supplementary Table 3: Relationships between people and dogs in study settings}

\begin{tabular}{|c|c|}
\hline \multicolumn{2}{|r|}{ Location: Northern Peninsular Area (NPA), Queensland } \\
\hline Source & Quote \\
\hline $\begin{array}{l}\text { Local } \\
\text { Resident }\end{array}$ & .. most dogs here just bark ... people only bitten in a blue moon \\
\hline $\begin{array}{l}\text { Human } \\
\text { Health } \\
\text { Worker }\end{array}$ & $\begin{array}{l}\text { Sometimes the dogs are cruising around in groups or packs and you have to be } \\
\text { a bit wary at night-time in Bamaga if you're on your own. }\end{array}$ \\
\hline $\begin{array}{l}\text { Local } \\
\text { Resident }\end{array}$ & $\begin{array}{l}\text { We do not see diseases. We just see general lack of care ... People spend a lot } \\
\text { of money on dogs to get them up here [from Cairns], then they won't spend the } \\
\text { money to look after them... The freight is like } 200 \text { [dollars] or something. }\end{array}$ \\
\hline $\begin{array}{l}\text { Community } \\
\text { Leader / } \\
\text { Elder }\end{array}$ & $\begin{array}{l}\text { Some in community believe that they have a right to have as many dogs as the } \\
\text { want, whether they care for them or not ... and lots of people have no idea how } \\
\text { to set their budgets - so they are asking neighbours for sugar and tea ... } \\
\text { sometimes they are forced to make choices ... do they feed their dogs or their } \\
\text { kids }\end{array}$ \\
\hline $\begin{array}{l}\text { Local } \\
\text { Resident }\end{array}$ & $\begin{array}{l}\text { I am a single mum I have } 2 \text { dogs and } 5 \text { children... even trying to keep your } \\
\text { fence intact - to stop other dogs from getting in is a battle with council ... I am } \\
\text { not rich so I cannot afford a whole roll of fencing wire to fix a hole in the fence ... } \\
\text { because it was not my dogs that did it .. someone else's dog that was hungry }\end{array}$ \\
\hline Teacher & $\begin{array}{l}\text { you see them [dogs] climbing up on tables, pulling bags down, ripping up lunch } \\
\text { boxes, ripping up garbage bags ... not just at school... they're everywhere... }\end{array}$ \\
\hline $\begin{array}{l}\text { Local } \\
\text { Resident }\end{array}$ & $\begin{array}{l}\text { The only time that [animal control] will take action is when the dog is a threat, a } \\
\text { menace to the community ... growling is not enough .... it needs to bite someone } \\
\text { first - then they take action }\end{array}$ \\
\hline $\begin{array}{l}\text { Animal } \\
\text { Control } \\
\text { Worker }\end{array}$ & $\begin{array}{l}\text { We come down to pick up wandering dogs ... we say there are too many dogs } \\
\ldots 2 \text { dogs per house ... but they say no its for hunting ... it's a high cost of living } \\
\text { around town .. everything is very expensive ... people have dogs for hunting }\end{array}$ \\
\hline $\begin{array}{l}\text { Indigenous } \\
\text { Ranger }\end{array}$ & $\begin{array}{l}\text { Different between city and remote ... in a remote we have a yard and a pen - } \\
\text { hunting dogs and older ones stay home and guard the house }- \text { others just roam } \\
\ldots \text { A lot of dogs are not fed enough ... dogs from community go down to tip .. we } \\
\text { see them ... they become scavengers and then strays ... }\end{array}$ \\
\hline \multicolumn{2}{|r|}{ Location: East Arnhem Land (EAL), Northern Territory } \\
\hline $\begin{array}{l}\text { Community } \\
\text { Leader / } \\
\text { Elder }\end{array}$ & $\begin{array}{l}\text { In Yolngu we give some dogs skin [sacred] names .. And if someone hits that } \\
\text { dog or runs over it then there is trouble ... lots of arguments ... people upset }\end{array}$ \\
\hline $\begin{array}{l}\text { Indigenous } \\
\text { Ranger }\end{array}$ & $\begin{array}{l}\text { They're a bit like humans, those dogs [with skin names]. They've got to be } \\
\text { chosen ... somebody has to decide to look after the dog properly then the dog } \\
\text { decides to go and live in this family's yard. }\end{array}$ \\
\hline $\begin{array}{l}\text { Local } \\
\text { Resident }\end{array}$ & $\begin{array}{l}\text { You know a dog, a family dog that is getting old and dies... we don't go } \\
\text { chucking it anywhere it needs to be buried properly }\end{array}$ \\
\hline $\begin{array}{l}\text { Indigenous } \\
\text { Ranger }\end{array}$ & $\begin{array}{l}\text { Some dogs ... follow their owner everywhere because the owners have } \\
\text { extended family. So the dog follows the - the owner everywhere and where she } \\
\text { goes or he goes the dog goes with them }\end{array}$ \\
\hline $\begin{array}{l}\text { Animal } \\
\text { Health } \\
\text { Worker }\end{array}$ & $\begin{array}{l}\text { People don't even understand having fences. So when fences are put up ... } \\
\text { Um, a lot of community members say... oh isn't it wonderful we can lock the } \\
\text { dogs outside the yard, get out and clean, and no humbug from the dogs. }\end{array}$ \\
\hline $\begin{array}{l}\text { Human } \\
\text { Health } \\
\text { Worker }\end{array}$ & $\begin{array}{l}\text { so many times, people ask me to help me with their dogs. ... Other nurses say } \\
\text { they don't want to have anything to do with the animals, but that affects their } \\
\text { relationship with the families, because they are then not part of the holistic }\end{array}$ \\
\hline
\end{tabular}




\begin{tabular}{|c|c|}
\hline & approach. Dogs are part of the family. \\
\hline $\begin{array}{l}\text { Community } \\
\text { Leader / } \\
\text { Elder }\end{array}$ & $\begin{array}{l}\text { People think that a sick dog is something that just happens in the normal day to } \\
\text { day events. Bad news spreads quickly if [an animal health worker] does } \\
\text { something to upset a family, because of cultural connection between Yolngu } \\
\text { and dogs. }\end{array}$ \\
\hline $\begin{array}{l}\text { Community } \\
\text { Leader / } \\
\text { Elder }\end{array}$ & $\begin{array}{l}\text { Everybody has connections to dogs through their song-lines, and stories about } \\
\text { dogs that the old people used to talk about a lot. In the Yolngu spirit. }\end{array}$ \\
\hline $\begin{array}{l}\text { Local } \\
\text { Resident }\end{array}$ & $\begin{array}{l}\text { Dog is not alone from humans. Through the spirit, the journey, we feel them like } \\
\text { they are close. Some say this is "dog rubbish, why are you keeping these } \\
\text { dogs?" This is not rubbish. We treating them dogs like us. What we eat, they } \\
\text { eat. Yolngu people used to use dogs to hunt kangaroo (P), find wild honey. The } \\
\text { dogs eat this too. In older times - had dingoes. They are the most smart dogs; } \\
\text { the dogs we have now are less smart. }\end{array}$ \\
\hline \multicolumn{2}{|r|}{ Location: Cairns, Queensland } \\
\hline $\begin{array}{l}\text { Local } \\
\text { Resident }\end{array}$ & $\begin{array}{l}\text { Most people do not stick to the rules ... there are two dog cultures here [in } \\
\text { Cairns]: a laissez faire sort of semi-responsible people, and then the pig dog } \\
\text { culture where the dogs are really well trained but have restrictions so do not go } \\
\text { into public space }\end{array}$ \\
\hline $\begin{array}{l}\text { Local } \\
\text { Resident }\end{array}$ & $\begin{array}{l}\text { Another culture in Cairns are the people who do not desex their dogs - where I } \\
\text { live in the South there are lots of roaming males - there are a lot of people who } \\
\text { do not look after their dogs... They feed them but they don't immunise them or } \\
\text { do anything else... because of the cost }\end{array}$ \\
\hline $\begin{array}{l}\text { Local } \\
\text { Resident }\end{array}$ & $\begin{array}{l}\text { where we live, every second person's house around our place, especially, has } \\
\text { got a dog. They're in very close proximity.. }\end{array}$ \\
\hline $\begin{array}{l}\text { Local } \\
\text { Resident }\end{array}$ & $\begin{array}{l}\text { We live in [BLINDED] - we don't have a dog but we see loads on the streets } \\
\text { and most people comply - and about } 90 \% \text { of dogs I see are on a leash }\end{array}$ \\
\hline $\begin{array}{l}\text { Local } \\
\text { Resident }\end{array}$ & $\begin{array}{l}\text { Kids getting bitten.. People going to court.. It's got to the point where dog parks } \\
\text { in Cairns have security guards ... policing people to make sure the dog has a } \\
\text { lead on when out of the off-leash area ... }\end{array}$ \\
\hline $\begin{array}{l}\text { Local } \\
\text { Resident }\end{array}$ & $\begin{array}{l}\text { It depends where you live ...every couple of days I will see a dog wandering } \\
\text { around without an owner ... some people don't care ... Just leave their gates } \\
\text { open }\end{array}$ \\
\hline $\begin{array}{l}\text { Local } \\
\text { Resident }\end{array}$ & $\begin{array}{l}\text { It's very rare that you'll find a dingo that's - that's not crossbred. They're } \\
\text { considered as a pest... }\end{array}$ \\
\hline
\end{tabular}


Supplementary Table 4: Examples of participant responses to control measures in AUSVETPLAN Stages 1

\begin{tabular}{|c|c|c|}
\hline \multicolumn{3}{|r|}{ Location: Northern Peninsula Area (NPA), Queensland } \\
\hline Source & Control Measure & Quote \\
\hline $\begin{array}{l}\text { Local } \\
\text { Resident }\end{array}$ & Communication & $\begin{array}{l}\text { If you explain everything to us first then we know ... but if you come and say we need to do all these things to your dog and maybe take } \\
\text { it away then, we will say why? why? }\end{array}$ \\
\hline $\begin{array}{l}\text { Indigenous } \\
\text { Ranger }\end{array}$ & Communication & $\begin{array}{l}\text { Some people have the dog as their totem, ... but if they understood the disease and stuff ... it may be different } \ldots \text { but it's about the } \\
\text { awareness and the education ... }\end{array}$ \\
\hline $\begin{array}{l}\text { Animal } \\
\text { control } \\
\text { Worker }\end{array}$ & Canine Census & $\begin{array}{l}\text { Dogs wander because not being fed - even though they are owned and claimed by someone People know who's dog is whose - } \\
\text { especially the kids" }\end{array}$ \\
\hline $\begin{array}{l}\text { Local } \\
\text { Resident }\end{array}$ & $\begin{array}{l}\text { Contact tracing / } \\
\text { Case finding }\end{array}$ & $\begin{array}{l}\text { I think if we do have an outbreak here ... it will spread like that (clicks fingers) because the dogs are always fighting ... they wander all } \\
\text { the time ... it will spread really quick }\end{array}$ \\
\hline $\begin{array}{l}\text { Local } \\
\text { Resident }\end{array}$ & $\begin{array}{l}\text { Quarantine / } \\
\text { Depopulation }\end{array}$ & $\begin{array}{l}\text { When an animal become part of your family they stay your family ... they are family they provide for you, they protect you, you know ... } \\
\text { it would be hard, but you might have to let go }\end{array}$ \\
\hline $\begin{array}{l}\text { Indigenous } \\
\text { Ranger }\end{array}$ & Depopulation & ... They might just want to keep hunting dogs - would be happy to get rid of the others... " \\
\hline $\begin{array}{l}\text { Animal } \\
\text { control } \\
\text { worker }\end{array}$ & Depopulation & $\begin{array}{l}\ldots \text { we come down to pick up wandering dogs ... we say there are too many dogs } \ldots 2 \text { dogs per house ... but they say no its for } \\
\text { hunting } \ldots \text { it's a high cost of living around town } . . \text { everything is very expensive ... people have dogs for hunting.. }\end{array}$ \\
\hline $\begin{array}{l}\text { Indigenous } \\
\text { Ranger }\end{array}$ & Depopulation & $\begin{array}{l}\text {.. its [a dog] nice and cute and cuddly and hmmm, but if the dog becomes a big problem then they get out ... do not want to know...... } \\
\text { They might just want to keep hunting dogs - would be happy to get rid of the others... }\end{array}$ \\
\hline \multicolumn{3}{|r|}{ Location: East Arnhem Land (EAL), Northern Territory } \\
\hline $\begin{array}{l}\text { Community } \\
\text { Leader / } \\
\text { Elder }\end{array}$ & Communication & $\begin{array}{l}\text { First the people would like to know ... some education would be good... but it can takes week to get a message out ... to talk to } \\
\text { people... we want be more engaged in this not only here but out in the homelands too where they have millions of dogs out there. }\end{array}$ \\
\hline $\begin{array}{l}\text { Human } \\
\text { Health } \\
\text { Worker }\end{array}$ & Communication & $\begin{array}{l}\text { In Gapuwiyak, there are a lot of dreaming dogs. Don't want the ancestor to suffer through the dog. So this can be an approach [to get } \\
\text { people to modify their behaviour]- to stop the suffering. }\end{array}$ \\
\hline $\begin{array}{l}\text { Indigenous } \\
\text { Ranger }\end{array}$ & Communication & $\begin{array}{l}\text { If it did break out it would - you could take weeks to - to get the message out. Like you can't get hold of people sometimes. They may } \\
\text { not even be in the Northern Territory, the people [traditional owners/community elders] that you need to talk to. }\end{array}$ \\
\hline Indigenous & Canine Census & There's a few stray dogs... Those dogs [are problems in the event of a rabies outbreak], because we can't control them - - because \\
\hline
\end{tabular}




\begin{tabular}{|c|c|c|}
\hline Ranger & & some - some are owned but most are stray dogs. \\
\hline $\begin{array}{l}\text { Indigenous } \\
\text { Ranger }\end{array}$ & $\begin{array}{l}\text { Canine Census / } \\
\text { Quarantine }\end{array}$ & $\begin{array}{l}\text { Well, ask the owner if - if it's his or hers - or her dog. If they say no, then you could take it... Yeah, you would have to virtually ask } \\
\text { everybody [for each dog] ... or put them all in a pen, and then wait for the owner to come to you... All in separate pens. And maybe } 20 \\
\text { mm of mesh each side of it. }\end{array}$ \\
\hline $\begin{array}{l}\text { Indigenous } \\
\text { Ranger }\end{array}$ & $\begin{array}{l}\text { Contact tracing / } \\
\text { Case finding }\end{array}$ & $\begin{array}{l}\text { Like it could well and truly get a hold - a strong foothold before anyone even notices, let alone does anything about it .. Yeah, because } \\
\text { if there were } 10 \text { puppies (infected) with rabies they could be anywhere from here to Numbulwar in a day - - I reckon if it happened } \\
\text { here it would - I don't reckon you would stop it. I don't mean to be negative, but by the time you realised that it was here. I don't think } \\
\text { anyone could keep up. }\end{array}$ \\
\hline $\begin{array}{l}\text { Community } \\
\text { Leader / } \\
\text { Elder }\end{array}$ & Quarantine & $\begin{array}{l}\text { If a dog became ill it would effect the owners and the children close to the dog }- \text { talk to them ... why we are doing it }- \text { so the person } \\
\text { who doesn't know why we are moving your dog from your home to a compound - you know sometimes it's a hurtful thing and the hurt } \\
\text { comes back" }\end{array}$ \\
\hline $\begin{array}{l}\text { Indigenous } \\
\text { Ranger }\end{array}$ & Quarantine & $\begin{array}{l}\text {.. the only thing that would work I reckon... is taking over management of them [the dogs] ... So on the football field get a compound } \\
\text { set up or something, a camp ground. }\end{array}$ \\
\hline \multicolumn{3}{|r|}{ Location: Cairns, Queensland } \\
\hline $\begin{array}{l}\text { Local } \\
\text { Resident }\end{array}$ & Communication & $\begin{array}{l}\text { I would say you educate the people so that if they get bitten they know they need to go and see someone immediately, but you wouldn't } \\
\text { force them, you put the resources to doing the dogs. }\end{array}$ \\
\hline $\begin{array}{l}\text { Local } \\
\text { Resident }\end{array}$ & Communication & $\begin{array}{l}\text { If all of a sudden the authorities say ... "guess what, we've had our first case [of rabies], everyone will panic and will either - as I said, } \\
\text { surrender their dogs, or hide their dogs, so they don't get vaccine - so, there'll be a lot of people stressed out. }\end{array}$ \\
\hline $\begin{array}{l}\text { Local } \\
\text { Resident }\end{array}$ & Communication & $\ldots$ the dog might accidentally bite you, have they got rabies? Like, I think - I think it'll put a lot of fear into the community... \\
\hline $\begin{array}{l}\text { Local } \\
\text { Resident }\end{array}$ & $\begin{array}{l}\text { Communication / } \\
\text { Depopulation }\end{array}$ & $\begin{array}{l}\text { we should start [education] now. Because otherwise, it'll bring about scare tactics. [In the event of a rabies outbreak] People will try and } \\
\text { do their own preventative measures like hiding dogs or surrendering to the pounds and stuff like that, if they don't actually understand. }\end{array}$ \\
\hline $\begin{array}{l}\text { Local } \\
\text { Resident }\end{array}$ & Quarantine & $\begin{array}{l}\text { It would have to be if your dog gets out, we take it and we quarantine it and that's going to be a cost to you too, to quarantine it ... But } \\
\text { you know, unless we come in firm, people are just going to go out walking, take them off leash, no muzzle. }\end{array}$ \\
\hline $\begin{array}{l}\text { Local } \\
\text { Resident }\end{array}$ & $\begin{array}{l}\text { Quarantine / } \\
\text { Depopulation }\end{array}$ & $\begin{array}{l}\text { dogs that are at large should be picked up, with owners that aren't compliant, that aren't looked after properly or aren't, if the owners } \\
\text { aren't coming forward to claim them [from quarantine] or anything like that, so they should be destroyed. }\end{array}$ \\
\hline $\begin{array}{l}\text { Local } \\
\text { Resident }\end{array}$ & All Interventions & $\begin{array}{l}\text { We would cope fine with this ... we are fairly educated .. But there is a whole bunch of people who would not cope so well ... Surely you } \\
\text { would need to target low SES areas }\end{array}$ \\
\hline $\begin{array}{l}\text { Local } \\
\text { Resident }\end{array}$ & All Interventions & $\begin{array}{l}\text { Zero tolerance is well tolerated in Cairns! ..., we are - we are a community that is familiar with um, with crisis management. Because } \\
\text { every year we all go through cyclone season, yeah" }\end{array}$ \\
\hline $\begin{array}{l}\text { Local } \\
\text { Resident }\end{array}$ & All Interventions & I got caught up in a Hendra outbreak: Let me tell you Biosecurity are really scary people!! \\
\hline
\end{tabular}


Supplementary Table 5: Examples of participant responses to control measures in AUSVETPLAN Stages 2 \& 3

\begin{tabular}{|c|c|c|}
\hline \multicolumn{3}{|r|}{ Location: Northern Peninsula Area (NPA), Queensland } \\
\hline Source & Control Measure & Quote \\
\hline $\begin{array}{l}\text { Local } \\
\text { Resident }\end{array}$ & $\begin{array}{l}\text { Restrictions on } \\
\text { movement }\end{array}$ & $\begin{array}{l}\text { Even though we have a fence they will find a way out .. they know your families' places - so even though you're not at home they just } \\
\text { go and see if other family members are at their home ... and then they hang out there" }\end{array}$ \\
\hline $\begin{array}{l}\text { Indigenous } \\
\text { Ranger }\end{array}$ & $\begin{array}{l}\text { Restrictions on } \\
\text { movement }\end{array}$ & $\begin{array}{l}\text {.. don't think so [people will lock up their dogs] ... because there is a lot of dogs running around ... because houses have no fences, } \\
\text { have broken fences, .... You know dogs, you feed them ... one hour later they are going to take off ... looking for food ... And chains ... } \\
\text { dogs bark a lot - annoy the neighbours ... chains make them aggressive ... }\end{array}$ \\
\hline $\begin{array}{l}\text { Local } \\
\text { Resident }\end{array}$ & $\begin{array}{l}\text { Restrictions on } \\
\text { movement }\end{array}$ & ... now some of us have good fences ... but the dogs are jumping fences ... nothing changes .. \\
\hline $\begin{array}{l}\text { Indigenous } \\
\text { Ranger }\end{array}$ & $\begin{array}{l}\text { Restrictions on } \\
\text { movement }\end{array}$ & ... some people own 6 dogs $\ldots$ feeding 6 dogs... they won't be able to manage $\ldots$ \\
\hline $\begin{array}{l}\text { Indigenous } \\
\text { Ranger }\end{array}$ & $\begin{array}{l}\text { Restrictions on } \\
\text { movement }\end{array}$ & ..not hunting for 3 months - food prices ... would skyrocket... anything could happen ... \\
\hline $\begin{array}{l}\text { Local } \\
\text { Resident }\end{array}$ & $\begin{array}{l}\text { Restrictions on } \\
\text { movement }\end{array}$ & $\begin{array}{l}\text { We don't not work for big money up here and dog food is very expensive so we feed them left over scraps - the thing that makes it } \\
\text { difficult is that when I feed my dog other dogs come to get a feed ... no matter what I do, the gates are locked, they will find a way .. } \\
\text { they will dig under a make a hole ... I just run out of food ... that's why I only have } 1 \text { dog... }\end{array}$ \\
\hline $\begin{array}{l}\text { Local } \\
\text { Resident }\end{array}$ & $\begin{array}{l}\text { Restrictions on } \\
\text { movement }\end{array}$ & $\begin{array}{l}\text { If it is serious ... we would have to do something about it and keep them [dogs] in - need to make dog food cheaper ... dogs important } \\
\text { because they provide food for the family ... they are part of the clan group }\end{array}$ \\
\hline $\begin{array}{l}\text { Indigenous } \\
\text { Ranger }\end{array}$ & Vaccination & $\ldots$ vaccines are not a problem ... all dogs coming from the Torres Strait should be vaccinated before they get here \\
\hline $\begin{array}{l}\text { Indigenous } \\
\text { Ranger }\end{array}$ & $\begin{array}{l}\text { Vaccination / } \\
\text { Quarantine }\end{array}$ & $\begin{array}{l}\text { We need to target dogs [for vaccination] - because they hang out together - grow up together, because they won't separate ...need to } \\
\text { do this before it got into the dingoes }\end{array}$ \\
\hline
\end{tabular}




\begin{tabular}{|c|c|c|}
\hline $\begin{array}{l}\text { Indigenous } \\
\text { Ranger }\end{array}$ & $\begin{array}{l}\text { Vaccination / } \\
\text { Depopulation }\end{array}$ & Trapping and vaccinating dingoes would be OK - but no culling ... we don't do shooting ... but our pig traps could catch 'em... \\
\hline $\begin{array}{l}\text { Indigenous } \\
\text { Ranger }\end{array}$ & All interventions & If the rabies do a lot in dingoes - our human life is more important ... but if it's healthy it should be left alone! \\
\hline \multicolumn{3}{|r|}{ Location: East Arnhem Land (EAL), Northern Territory } \\
\hline $\begin{array}{l}\text { Indigenous } \\
\text { Ranger }\end{array}$ & $\begin{array}{l}\text { Restrictions on } \\
\text { movement }\end{array}$ & $\begin{array}{l}\text { At least they have got those plans rather than just going killing all the dogs.... Probably a good start here would be that every house } \\
\text { was fenced properly. }\end{array}$ \\
\hline $\begin{array}{l}\text { Indigenous } \\
\text { Ranger }\end{array}$ & $\begin{array}{l}\text { Restrictions on } \\
\text { movement }\end{array}$ & $\begin{array}{l}\ldots \text { the only thing that would work I reckon... is taking over management of them [the dogs] ... So on the football field get a compound } \\
\text { set up or something, a camp ground. }\end{array}$ \\
\hline $\begin{array}{l}\text { Community } \\
\text { Leader / } \\
\text { Elder }\end{array}$ & $\begin{array}{l}\text { Restrictions on } \\
\text { movement }\end{array}$ & $\begin{array}{l}\text { In the case of the disease could we set up a compound for the moving of the dogs from the community so they are together and not } \\
\text { running round? - this would be ok [e.g. not meet major resistance from the community] because of the sickness" }\end{array}$ \\
\hline $\begin{array}{l}\text { Community } \\
\text { Leader / } \\
\text { Elder }\end{array}$ & Vaccination & If this happens and rabies comes here ... the more dogs we can vaccinate the better \\
\hline $\begin{array}{l}\text { Indigenous } \\
\text { Ranger }\end{array}$ & $\begin{array}{l}\text { Vaccination / } \\
\text { Monitoring }\end{array}$ & $\begin{array}{l}\text { It's a hard question [how to manage dingoes] ...Just go out and - go out and trap them, build a trap for the, um, dingos yeah, or chuck } \\
\text { some bait ... You would still have to talk to all the, um, land owners... Yeah, it would be an in depth process. }\end{array}$ \\
\hline $\begin{array}{l}\text { Indigenous } \\
\text { Ranger }\end{array}$ & $\begin{array}{l}\text { Vaccination / } \\
\text { Depopulation }\end{array}$ & $\begin{array}{l}\text { they're [dingoes] sacred... for some tribes ... like you couldn't go culling them, but yeah.. you would just have to hope that } 70 \text { per cent } \\
\text { [vaccine coverage] gets done.. }\end{array}$ \\
\hline $\begin{array}{l}\text { Community } \\
\text { Leader / } \\
\text { Elder }\end{array}$ & All interventions & $\begin{array}{l}\text { Dogs and dingoes have feeling and humans have feelings, anything like that effects humans as well ... if they agree to what you say } \\
\text { the dog needs to be treated with respect" }\end{array}$ \\
\hline $\begin{array}{l}\text { Indigenous } \\
\text { Ranger }\end{array}$ & All interventions & $\begin{array}{l}\text { I think would help just to put the message out there. Even when we do our work we go out a couple of months ahead and, you know, } \\
\text { this is what we're going to do, this is how we're going to do it. }\end{array}$ \\
\hline \multicolumn{3}{|r|}{ Location: Cairns, Queensland } \\
\hline $\begin{array}{l}\text { Local } \\
\text { Resident }\end{array}$ & $\begin{array}{l}\text { Restrictions on } \\
\text { movement }\end{array}$ & $\begin{array}{l}\text { That's not an excuse. It's about sorry, you've got to keep your dog locked in the laundry. I'm sorry, but it's been - it's not for the rest of } \\
\text { its life.... Any responsible pet owner restrains their dogs correctly anyway }\end{array}$ \\
\hline $\begin{array}{l}\text { Local } \\
\text { Resident }\end{array}$ & $\begin{array}{l}\text { Restrictions on } \\
\text { movement }\end{array}$ & $\begin{array}{l}\text { You have a dog, you fence it. You contain it. ...but the problem is a lot of people don't have fencing, um, we know dogs slip collars, so } \\
\text { they go oh, my dog's on a lead, but they can still bite. So, although that's a good first step, it's not like, by doing that you'll - you'll be } \\
\text { safe or you're - you're keeping everybody safe. }\end{array}$ \\
\hline Local & Restrictions on & .. if you had to keep your dogs locked in, for say a month and it was dog lockdown for a month, ... we would find ways to keep them \\
\hline
\end{tabular}




\begin{tabular}{|c|c|c|}
\hline Resident & movement & safe and to - for as long as it took. \\
\hline $\begin{array}{l}\text { Local } \\
\text { Resident }\end{array}$ & Vaccination & $\begin{array}{l}\text { You vaccinate everyone's [dog] that's here in Cairns and we do the forced vaccination and then Tablelands, ... then you try and create a } \\
\text { circle around the wild animals }\end{array}$ \\
\hline $\begin{array}{l}\text { Local } \\
\text { Resident }\end{array}$ & Vaccination & If you're vaccinating and one of the wild dogs has already got it, then you've just wasted your time. \\
\hline $\begin{array}{l}\text { Local } \\
\text { Resident }\end{array}$ & Depopulation & $\begin{array}{l}\text { The biggest problem is I mean, I know what they were saying, but the other thing, the big thing that's come out now is that if you start } \\
\text { getting rid of dingoes, then your kangaroo population just goes crazy and then you lose, you know, so you need some sort of balance. }\end{array}$ \\
\hline $\begin{array}{l}\text { Local } \\
\text { Resident }\end{array}$ & Depopulation & um, we're not just talking about killing wild dogs, you'd be really significantly damaging the ecosystem \\
\hline $\begin{array}{l}\text { Local } \\
\text { Resident }\end{array}$ & r All interventions & $\begin{array}{l}\text { If it got into the wild population, to know that we've got um, rabies. We would need to do whatever it takes, ... [otherwise] you'd always } \\
\text { be living under the thought there could be rabies that comes back }\end{array}$ \\
\hline
\end{tabular}


Altman, J.C., \& Kerins, S. (2012). People on country: vital landscapes, Indigenous futures: Federation Press Sydney.

Animal Health Australia. (2011). Disease strategy: Rabies (Version 3.0). Australian Veterinary Emergency Plan (AUSVETPLAN). Canberra, ACT: Primary Industries Ministerial Council.

Aronson, S. (2010). Animal control management: A new look at a public responsibility: Purdue University Press.

Biosecurity Bill 2012, The Parliment of the Commonwealth of Australia (2012).

Borkan, J. (1999). Immersion/Crystallization. In B. Crabtree, \& W. Miller (Eds.), Doing Qualitative Research pp. 179-194). London: Sage.

Brookes, V.J., Degeling, C., \& Ward, M.P. (2018). Going viral in PNG-Exploring routes and circumstances of entry of a rabies-infected dog into Papua New Guinea. Social Science \& Medicine, 196, 10-18.

Brookes, V.J., Kennedy, E., Dhagapan, P., \& Ward, M.P. (2017). Qualitative research to Design sustainable community-Based surveillance for rabies in northern australia and Papua new guinea. Frontiers in Veterinary Science, 4.

Burgess, C.P., Johnston, F.H., Bowman, D.M., \& Whitehead, P.J. (2005). Healthy country: healthy people? Exploring the health benefits of Indigenous natural resource management. Australian and New Zealand journal of Public Health, 29, 117-122.

Burleigh, A., McMahon, S., \& Kiely, S. (2015). Owned dog and cat populations in remote Indigenous communities in the Northern Territory: a retrospective study. Australian Veterinary Journal, 93, 145-150.

Constable, S., Brown, G., Dixon, R., \& Dixon, R. (2008). Healing the Hand that Feeds you: Exploring Solutions for Dog and Community Health and Welfare in Australian Indigenous Cultures. International Journal of Interdisciplinary Social Sciences, 3, 219229.

Constable, S., Dixon, R., \& Dixon, R. (2010). For the love of dog: the human-dog bond in rural and remote Australian indigenous communities. Anthrozoös, 23, 337-349.

Dürr, S., \& Ward, M. (2015). Development of a novel rabies simulation model for application in a non-endemic environment. PLOS Neglected Tropical Diseases, 9, e0003876.

Dwyer, P.D., \& Minnegal, M. (2016). Wild dogs and village dogs in New Guinea: were they different? Australian Mammalogy, 38, 1-11.

Emerson, R., Fretz, R., \& Shaw, L. (1995). Writing Ethnographic Fieldnotes. Chicago: University of Chicago Press.

Gale, N.K., Heath, G., Cameron, E., Rashid, S., \& Redwood, S. (2013). Using the framework method for the analysis of qualitative data in multi-disciplinary health research. BMC Medical Research Methodology, 13, 117-117.

Garnett, S.T., Sithole, B., Whitehead, P.J., Burgess, C.P., Johnston, F.H., \& Lea, T. (2009). Healthy country, healthy people: policy implications of links between Indigenous human health and environmental condition in tropical Australia. Australian Journal of Public Administration, 68, 53-66.

Gould, G.S., Munn, J., Avuri, S., Hoff, S., Cadet-James, Y., McEwen, A., et al. (2013). "Nobody smokes in the house if there's a new baby in it": Aboriginal perspectives on tobacco smoking in pregnancy and in the household in regional NSW Australia. Women and Birth, 26, 246-253. 
Hampson, K., Coudeville, L., Lembo, T., Sambo, M., Kieffer, A., Attlan, M., et al. (2015). Estimating the Global Burden of Endemic Canine Rabies. PLOS Neglected Tropical Diseases, 9, e0003709.

Hudson, E.G., Brookes, V.J., \& Ward, M.P. (2017). Assessing the risk of a canine rabies incursion in Northern Australia. Frontiers in Veterinary Science, 4, 141.

Hudson, E.G., Dhand, N., Dürr, S., \& Ward, M.P. (2016). A Survey of Dog Owners in Remote Northern Australian Indigenous Communities to Inform Rabies Incursion Planning. PLoS Negl Trop Dis, 10, e0004649.

Johnston, F.H., Jacups, S.P., Vickery, A.J., \& Bowman, D.M. (2007). Ecohealth and Aboriginal testimony of the nexus between human health and place. EcoHealth, 4, 489-499.

Johnstone-Robertson, S.P., Fleming, P.J., Ward, M.P., \& Davis, S.A. (2017). Predicted Spatial Spread of Canine Rabies in Australia. PLOS Neglected Tropical Diseases, 11, e0005312.

Kovach, M. (2010). Indigenous methodologies: Characteristics, conversations, and contexts: University of Toronto Press.

Krippendorff, K. (2004). Content analysis: an introduction to its methodology. Thousand Oaks, CA: Sage.

Laycock, A., Walker, D., Harrison, N., \& Brands, J. (2011). Researching Indigenous Health: A Practical Guide for Researchers. Melbourne The Lowitja Institute.

Mort, M., Convery, I., Baxter, J., \& Bailey, C. (2005). Psychosocial effects of the 2001 UK foot and mouth disease epidemic in a rural population: qualitative diary based study. $B M J, 331,1234$.

Morters, M.K., Restif, O., Hampson, K., Cleaveland, S., Wood, J.L.N., \& Conlan, A.J.K. (2013). Evidence-based control of canine rabies: a critical review of population density reduction. Journal of Animal Ecology, 82, 6-14.

Musharbash, Y. (2017). Telling Warlpiri Dog Stories. Anthropological Forum, 27, 95-113.

Orr, Y. (2016). Interspecies semiotics and the specter of taboo: The perception and interpretation of dogs and rabies in Bali, Indonesia. American Anthropologist, 118, 67-77.

Pemberton, N., \& Worboys, M. (2007). Mad Dogs and Englishmen. New York: Palgrave Macmillan.

Putra, A.A.G., Hampson, K., Girardi, J., Hiby, E., Knobel, D., Mardiana, W., et al. (2013). Response to a rabies epidemic, Bali, Indonesia, 2008-2011. Emerging Infectious Diseases, 19, 648.

Redman-MacLaren, M., Mills, J., \& Tommbe, R. (2014). Interpretive focus groups: a participatory method for interpreting and extending secondary analysis of qualitative data. Global Health Action, 7, 6.

Robinson, C., \& Wallington, T. (2012). Boundary work: engaging knowledge systems in comanagement of feral animals on Indigenous lands. Ecology and Society, 17.

Rock, M., \& Degeling, C. (2013). Public Health Ethics and a Status for Pets as Person-Things. Journal of Bioethical Inquiry, 10, 485-495.

Rock, M., Rault, D., \& Degeling, C. (2017). Dog-bites, rabies and One Health: Towards improved coordination in research, policy and practice. Social Science \& Medicine, 187, 126-133.

Rose, D.B. (2011). Wild dog dreaming: Love and extinction: University of Virginia Press. 
Senior, K., Chenhall, R., McRae-Williams, E., Daniels, D., \& Rogers, K. (2006). Dogs and people in Aboriginal communities: Exploring the relationship within the context of the social determinants of health. Environmental Health, 6, 39.

Smith, B.P., \& Litchfield, C.A. (2009). A Review of the Relationship between Indigenous Australians, Dingoes (Canis dingo) and Domestic Dogs (Canis familiaris). Anthrozoös, 22, 111-128.

Smith, L. (2013). Decolonizing methodologies: Research and Indigenous peoples: Zed Books Ltd.

Sparkes, J., Ballard, G., \& Fleming, P.J. (2016a). Cooperative hunting between humans and domestic dogs in eastern and northern Australia. Wildlife Research, 43, 20-26.

Sparkes, J., Fleming, P., Ballard, G., Scott-Orr, H., Durr, S., \& Ward, M. (2015). Canine rabies in Australia: a review of preparedness and research needs. Zoonoses and Public Health, 62, 237-253.

Sparkes, J., McLeod, S., Ballard, G., Fleming, P.J., Körtner, G., \& Brown, W.Y. (2016b). Rabies disease dynamics in naïve dog populations in Australia. Preventive Veterinary Medicine, 131, 127-136.

Street, J., Cox, H., Lopes, E., Motlik, J., \& Hanson, L. (2018). Supporting youth wellbeing with a focus on eating well and being active: views from an Aboriginal community deliberative forum. Australian and New Zealand Journal of Public Health, 42, 127132.

Tenzin, \& Ward, M.P. (2012). Review of Rabies Epidemiology and Control in South, South East and East Asia: Past, Present and Prospects for Elimination. Zoonoses and Public Health, 59, 451-467.

Widyastuti, M.D.W., Bardosh, K.L., Sunandar, Basri, C., Basuno, E., Jatikusumah, A., et al. (2015). On dogs, people, and a rabies epidemic: results from a sociocultural study in Bali, Indonesia. Infectious Diseases of Poverty, 4, 30.

Windiyaningsih, C., Wilde, H., Meslin, F.X., Suroso, T., \& Widarso, H. (2004). The rabies epidemic on Flores Island, Indonesia (1998-2003). Journal Of The Medical Association Of Thailand, 87, 1389-1393.

Yin, R. (2002). Case Study Research: Design and Methods. Thousand Oaks, CA: Sage. 